Résumés des conférences et travaux

History and philology of medieval and Mughal India (XIIIth-XVIIIth century)

Topography and travel in Mughal Persian literature (1586-1665)

Topographie et voyage dans la littérature persane moghole (1586-1665)

\title{
Sunil Sharma
}

\section{OpenEdition}

\section{Journals}

Electronic version

URL: https://journals.openedition.org/ashp/1994

DOI: 10.4000/ashp.1994

ISSN: 1969-6310

\section{Publisher}

Publications de l'École Pratique des Hautes Études

\section{Printed version}

Date of publication: 1 September 2017

Number of pages: 317-318

ISSN: 0766-0677

\section{Electronic reference}

Sunil Sharma, "Topography and travel in Mughal Persian literature (1586-1665)", Annuaire de l'École pratique des hautes études (EPHE), Section des sciences historiques et philologiques [Online], 148 | 2017 Online since 04 October 2017, connection on 06 July 2021. URL: http://journals.openedition.org/ashp/ 1994 ; DOI: https://doi.org/10.4000/ashp.1994 


\title{
TOPOGRAPHY AND TRAVEL IN MUGHAL PERSIAN LITERATURE (1586-1665)
}

\author{
TOPOGRAPHIE ET VOYAGE DANS LA LITTÉRATURE \\ PERSANE MOGHOLE (1586-1665)
}

\author{
Conférences de M. Sunil SHarma, \\ université de Boston (États-Unis), \\ directeur d'études invité*
}

The monumental building projects and mobile lifestyle of the Mughal court in the sixteenth and seventeenth centuries were celebrated by poets, historians and artists through the innovative use of well-established tropes and genres. While previous scholarly studies have focused on the love lyric (ghazal) as a form that accompanied the spread of the language in an ever expanding Persianate region during these centuries, it is clear that poems of place were also in vogue, indicating that new literary developments were taking place that were tied to an understanding of the local or regional manifestation of a larger internationalism. This new found sense of place, linked to the growing awareness of the expansion of the cultural realm of Persian to include new regions, peoples, and aesthetics, resulted in a complicated nexus of politics, poetics, painting and patronage at the Mughal court. Beginning with a survey of the scholarship and pertinent issues on Mughal literary culture, I explore the different ways that court poets in the mid seventeenth century, both of Iranian and Indian origin, using the same poetic language but with different motivations, drew on a rich literary tradition and employed creative ways to describe imperial palaces, gardens, the city, its people, and the countryside, as they became increasingly conscious of local and regional differences within a vast and seemingly timeless Persianate cultural ecumene. Along with poetic sources, I also look at illustrated manuscripts as examples of the intertwining of visual and poetic metaphoric representations of place.

\section{Mughal Literary Culture: Periodization, Genres, and Languages} (lundi 5 mai 2014)

A survey of the state of scholarship on Mughal literary culture shows that although the empire and court were multi-lingual and diverse, Persian remained the dominant language through the sixteenth and seventeenth centuries. At the most elite level the literary community felt itself to be part of a larger Persian world beyond the borders of

* M. Sunil Sharma, aujourd'hui professeur, était professeur associé en littérature persanisée et comparative au Département de langues modernes et de littérature comparée qu'il dirigeait à l'université de Boston, au moment de son invitation comme directeur d'études invité. (Cf. http://www.bu.edu/wll/profile/

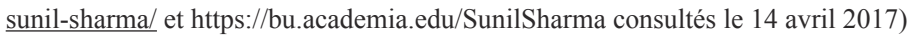


South Asia and a major trope in the writings of Iranian peripatetic poets was to describe their new home as a refuge for men of letters and learning, a tradition that goes back to Amīr Khusrau Dihlavī (1253-1325). But recent scholarship on the importance of Braj Bhasha and Sanskrit textual production at this time requires a re-examination of how the history of Mughal literature is written in terms of categories such as periods, genres and languages. Therefore, it is worth examining to what extent Mughal literary culture, defined largely by the dominance of Persian, was Indo-Persian.

\section{Mughal governors as patrons: 'Abd al-Rahīm Khānkhānān and Zafar Khān 'Ahsan' (lundi 12 mai 2014)}

The greatest patrons of poetry and the arts in general were members of the Mughal imperial family and governors of provinces, sometimes overlapping categories of people. The complex network of governors, especially during the reigns of Jahāngīr (r. 1605-27) and Shāh Jahān (r. 1628-56), who were mostly Iranian in origin, with many of them related or connected to the empress Nūr Jahān, controlled an elaborate system of patronage for poets and artists. The careers and patronage of governors such as 'Abd al-Rahīm Khānkhānān (d. 1627) in Ahmedabad (Gujarat) and Burhanpur (Khandesh), and Zafar Khān 'Ahsan' (d. 1662) in Kashmir, illustrate how provincial centers could create a congenial atmosphere for poets and artists that rivaled the capital.

\section{Kashmir as Paradise in Mughal Poetry (lundi 19 mai 2014)}

Kashmir became a major cultural and literary center in the period 1619-1658. Shāh Jahān's poet laureate, Kalīm Hamadānī (d. 1651), and about a dozen other Iranian poets visited Kashmir and wrote long narratives in masnavi form on its topography. These poems were the beginning of a literary fad that saw the emergence of a sub-genre of topographical poetry exclusively devoted to the beauty of the valley of Kashmir. Although there are some realistic descriptions of places and the flora and fauna of the region, these poems largely use the same metaphors praising urban spaces and metaphoric gardens. Indian-born poets of Persian who wrote about this Mughal province had a different relationship to the region and its place in the empire than the émigré poets.

\section{India and the Indian Woman in the Persian Imagination (lundi 2 juin 2014)}

The Persian ambivalence with reference to Mughal India resulted in a number of ways that the latter empire was depicted in poetry and painting, whether produced in Iran or in India itself. Alongside clichéd images of the place as a poetic utopia to a black hole, there was an Orientalist fascination with the religious and cultural practices found in the subcontinent. The figure of the Indian woman, as sati and courtesan, was central in poems by Nau'ī Khabhūshānī (d. 1609) and Vahīd Qazvīnī (d. 1708), which show up repeatedly in poetic and visual sources. How did these views of India and the Indian woman affect the cultural relationship of the Mughals and Safavids and how were these works received in India? 